\title{
Milk Fat Globule Membrane Proteome and Micronutrients in the Milk Lipid Fraction: Insights into Milk Bioactive Compounds
}

\author{
Michele Manoni $^{1}\left(\mathbb{D}\right.$, Donata Cattaneo ${ }^{1}(\mathbb{D})$, Sharon Mazzoleni ${ }^{1} \mathbb{D}$, Carlotta Giromini ${ }^{1,2} \mathbb{I D}$, Antonella Baldi ${ }^{1}$ \\ and Luciano Pinotti $1,2, *$ (D)
}

1 Department of Health, Animal Science and Food Safety, VESPA, Università di Milano, 20133 Milan, Italy; michele.manoni@unimi.it (M.M.); donata.cattaneo@unimi.it (D.C.); sharon.mazzoleni@unimi.it (S.M.); carlotta.giromini@unimi.it (C.G.); antonella.baldi@unimi.it (A.B.)

2 CRC I-WE (Coordinating Research Centre: Innovation for Well-Being and Environment), Università di Milano, 20133 Milan, Italy

* Correspondence: luciano.pinotti@unimi.it; Tel.: +39-02-503-15742

Citation: Manoni, M.; Cattaneo, D.; Mazzoleni, S.; Giromini, C.; Baldi, A.; Pinotti, L. Milk Fat Globule

Membrane Proteome and Micronutrients in the Milk Lipid Fraction: Insights into Milk Bioactive Compounds. Dairy 2021, 2, 202-217. https://doi.org/10.3390/dairy2020018

Academic Editor: Mailo Virto

Received: 29 January 2021

Accepted: 22 March 2021

Published: 12 April 2021

Publisher's Note: MDPI stays neutral with regard to jurisdictional claims in published maps and institutional affiliations.

Copyright: (c) 2021 by the authors. Licensee MDPI, Basel, Switzerland. This article is an open access article distributed under the terms and conditions of the Creative Commons Attribution (CC BY) license (https:/ / creativecommons.org/licenses/by/ $4.0 /)$.

\begin{abstract}
Milk lipids are composed of milk fat globules (MFGs) surrounded by the milk fat globule membrane (MFGM). MFGM protects MFGs from coalescence and enzymatic degradation. The milk lipid fraction is a "natural solvent" for macronutrients such as phospholipids, proteins and cholesterol, and micronutrients such as minerals and vitamins. The research focused largely on the polar lipids of MFGM, given their wide bioactive properties. In this review we discussed (i) the composition of MFGM proteome and its variations among species and phases of lactation and (ii) the micronutrient content of human and cow's milk lipid fraction. The major MFGM proteins are shared among species, but the molecular function and protein expression of MFGM proteins vary among species and phases of lactation. The main minerals in the milk lipid fraction are iron, zinc, copper and calcium, whereas the major vitamins are vitamin $A, \beta$-carotene, riboflavin and $\alpha$-tocopherol. The update and the combination of this knowledge could lead to the exploitation of the MFGM proteome and the milk lipid fraction at nutritional, biological or technological levels. An example is the design of innovative and value-added products, such as MFGM-supplemented infant formulas.
\end{abstract}

Keywords: milk fat globules; milk proteins; comparative proteomics; milk lipid fraction; milk minerals; lipophilic vitamins

\section{Introduction}

Milk is nature's most complete food because it is an essential source of nutrients and bioactive compounds such as immunoglobulins, antimicrobial proteins, oligosaccharides, phospholipids, hormones, minerals and vitamins [1,2]. Milk is an oil-in-water emulsion, and milk lipids are organized as lipid droplets composed of a hydrophobic core surrounded by a hydrophilic membrane. These two components are called milk fat globule (MFG) core and milk fat globule membrane (MFGM), respectively [3-5]. MFGM represents 2-6\% of the total MFGs mass and is composed of $60 \%$ proteins and $40 \%$ lipids [6]. Milk lipids are the major source of dietary energy for newborns for most mammalian species [7]. For example, human milk lipids provide $44 \%$ of the energy supply to newborns [8]. Milk lipids exert many bioactive functions in newborns, by contributing to the establishment of the immune system, the maturation of the gastrointestinal tract and of the microbiota, actively participating in lipid metabolism, building cellular membranes and sustaining neurodevelopment $[2,8]$. The milk lipid fraction acts as a "natural carrier" for the milk compounds that retain these bioactive properties [9]. These compounds are mainly phospholipids, sphingolipids and proteins of the MFGM, lipophilic vitamins, minerals and cholesterol. Therefore, it is clear that lipogenesis is a process that deeply influences the bioactive role of milk. 
In dairy ruminants, the formation and maturation processes of MFGs are related to the lipid synthesis in the mammary epithelial cells. Long-chain fatty acids (LCFAs) derive from dietary sources and mobilization of body reserves, whereas short- and mediumchain fatty acids (SCFAs and MCFAs, respectively) derive from de novo synthesis in the mammary epithelial cells [10]. LCFA uptake by mammary epithelial cells is mediated by FA transporters, such as fatty acid binding protein (FABP) and acyl-CoA binding protein $(\mathrm{ACBP})$, and FA translocator CD36, whereas passive diffusion through cellular membranes plays a minor role $[10,11]$. Once in the cells, fatty acids aggregate to form larger triglyceride droplets in the endoplasmic reticulum (ER), from which they are then secreted in the cytoplasm. The secretion implies that the triglyceride droplets are enclosed in a monolayer deriving from the ER membrane. This monolayer is composed of polar lipids and proteins of the ER membrane and is the first component of the MFGM. In the cytoplasm, the droplets tend to aggregate with each other, producing larger globules while reaching the apical pole of the cell. At this stage, the globules are finally secreted as mature MFGs, surrounded by a bilayer membrane deriving from the plasma membrane of the cell. This membrane is the second component of the MFGM. The result is that MFGs are enclosed in a trilayer membrane, named MFGM $[4,6,12]$. The MFG core is composed of non-polar lipids (e.g., triglycerides, $98 \%$ of total milk lipids), whereas the major components of MFGM are polar lipids (e.g., phospholipids, glycolipids and sphingolipids, 1-2\% of total milk lipids), proteins and cholesterol from the ER membrane and the plasma membrane of the mammary epithelial cells [6]. There is an association between the MFG size and the content of MFGM. The ratio is given by the amount of MFGM (i.e., phospholipids) per unit mass of fat. Smaller globules have a higher content of MFGM than larger globules; therefore, the ratio is higher for smaller globules [13].

In the last decades, research has focused on the characterization of MFGM and on the exploitation of its properties to design and produce value-added products. The main examples are the infant formulas supplemented with MFGM. This supplementation can reduce the gap between the nutritional and bioactive properties of human breast milk and infant formulas [14,15]. Alongside the progress in this area, the research has been less concerned both with the industrial exploitation of the MFGM proteome and with the comprehension of the content of minor components of the milk lipid fraction.

The MFGM proteome represents the entire protein content of the milk lipid fraction. Since the MFGM proteome is a unique pool of bioactive proteins, a deeper comprehension of the proteome of various species and the comparative analyses between species and phases of lactation could be exploited to design products particularly enriched in specific bioactive proteins of the MFGM.

The minor components of the milk lipid fraction are primarily minerals and lipophilic vitamins. These components are embedded in the MFG core and in the MFGM. The fat fraction acts as a "natural carrier" for these compounds, increasing their bioaccessibility and bioavailability. Understanding the micronutrient content of the fat fraction could lead to their technological exploitation for the design of value-added products, in concert with the MFGM proteome (that acts as a scaffold for the binding of minerals and vitamins to MFGs) and the bioactive polar lipids.

In this review we discussed the similarities and differences regarding the composition of the MFGM proteome of various species, highlighting the properties of the human and bovine MFGM proteome. Then, we revised the existing literature about the content and the distribution of micronutrients in the milk lipid fraction of human and bovine milk. The aim of the review is to provide an overview of the minor constituents of the milk lipid fraction, discussing their bioactive properties and suggesting innovative attempts of implementing the findings present in the literature about these topics.

\section{MFGM Proteome and Comparative Proteomics}

Milk and dairy products are an essential source of bioactive proteins and peptides [16]. Their bioactivity is exerted following gastrointestinal digestion and peptide release, acting 
directly on the intestinal epithelium or being adsorbed into the bloodstream. Several studies focused on the relation between the bioactivity of milk proteins and peptides and the gastrointestinal digestion, which can be simulated by an in vitro approach, to assess whether digestion could affect the bioactive role of proteins and peptides. The studies focused on the application of in vitro digestion both to caseins and whey proteins $[17,18]$ and also to the MFGM proteins [19-21]. All the studies reported above confirm that milk proteins are digested along the gastrointestinal tract, but the peptides or the metabolites produced by the digestion can either exert their bioactive role on the intestinal epithelium or influence the microbiota.

MFGM proteins represent $25-60 \%$ of the total mass of the MFGM and $1-4 \%$ of the total proteins of milk. The major MFGM proteins in bovine milk are adipophilin (ADPH), butyrophilin (BTN), mucin 1 (MUC1), xanthine dehydrogenase/oxidase (XDH/XO), CD36, lactadherin, periodic acid Schiff III (PAS III) and fatty acid-binding protein (FABP) [22,23]. These proteins exert wide and varied bioactive properties. For example, ADPH controls the trafficking of lipids towards the MFGs [6]. BTN is a member of the immunoglobulin superfamily. It has a structural role because it connects the inner and the outer MFGM membrane by binding $\mathrm{XDH} / \mathrm{XO}$ and $\mathrm{ADPH}$ in a tripartite superstructure. BTN1A1 is the main isoform in human MFGM and regulates the lipid secretion in milk [24]. MUC1 is a member of the mucins family. It is a glycoprotein with a highly glycosylated extracellular domain, which can act as decoy receptor, thus exerting an anti-adhesive action against pathogens. In addition, the action of MUC1 can be enhanced by the synergy with $\mathrm{XDH} / \mathrm{XO}$. $\mathrm{XDH} / \mathrm{XO}$ is a redox enzyme that exerts its antimicrobial role by producing reactive oxygen and nitrogen species [6,25]. Lactadherin, also known as PAS 6/7 or MFG-E8, is involved in the immune response and in the regulation of apoptosis. FABP is a fatty acid transporter and regulates the transport of LCFA into the mammary epithelial cells, a key step in the synthesis of triglycerides and phospholipids [6].

The use of proteomics techniques enabled a better comprehension of the role of MFGM proteome in milk and allowed to identify a higher number of MFGM proteins across all species. In addition, comparative proteomics analyses were performed to elucidate the variations and the similarities of MFGM proteome among species and phases of lactation [26]. The main species considered were firstly human and bovine [27], then more recent studies included other species such as goat, yak, buffalo, horse, camel and donkey [28-30]. It is known that the milk composition varies between colostrum, the first phase of lactation, and later lactation phases [31], and so it is also for the proteome of the MFGM [32]. Table 1 lists the most recent articles focused on comparative proteomics analyses of MFGM proteome.

Table 1. List of research articles and reviews about comparative proteomics analyses among species and phases of lactation. Articles are listed by year and according to the different animal species.

\begin{tabular}{ccc}
\hline Samples & Objective & Main Findings \\
\hline Human colostrum & $\begin{array}{c}\text { Update the human colostrum } \\
\text { MFGM proteome }\end{array}$ & $\begin{array}{c}107 \text { proteins identified; 46\% were typical MFGM } \\
\text { proteins (e.g., lactadherin and BTN) }\end{array}$ \\
\hline $\begin{array}{c}\text { Human milk from 1,2,3,6, } \\
\text { and 12 months of lactation }\end{array}$ & $\begin{array}{c}\text { Examine the variations of human } \\
\text { MFGM proteins during lactation }\end{array}$ & $\begin{array}{c}\text { Human MFGM proteins: cell communication } \\
\text { and signal transduction, immune function, } \\
\text { metabolism and energy production; Variations } \\
\text { during the course of lactation }\end{array}$ \\
\hline $\begin{array}{c}\text { Human colostrum and mature } \\
\text { milk }\end{array}$ & $\begin{array}{c}\text { Identify the MFGM } \\
\text { phosphoproteome }\end{array}$ & $\begin{array}{c}\text { 323 phosphorylation sites and 203 } \\
\text { phosphoproteins; 48 MFGM phosphoproteins } \\
\text { differentially expressed between colostrum and } \\
\text { mature milk }\end{array}$ \\
\hline [35]
\end{tabular}


Table 1. Cont.

\begin{tabular}{|c|c|c|c|}
\hline Samples & Objective & Main Findings & Ref. \\
\hline \multicolumn{4}{|c|}{ Bovine } \\
\hline $\begin{array}{l}\text { Holstein cow milk in } \\
\text { mid-lactation }\end{array}$ & Update the proteome & $\begin{array}{c}\text { Proteins identified (120) responsible for } \\
\text { membrane/protein trafficking }(23 \%) \text { and cell } \\
\text { signaling }(23 \%)\end{array}$ & [36] \\
\hline $\begin{array}{l}\text { Holstein cow colostrum and } \\
\text { 7-days milk }\end{array}$ & $\begin{array}{l}\text { Quantify protein changes in } \\
\text { bovine MFGM from colostrum } \\
\text { and 7-days milk. }\end{array}$ & $\begin{array}{l}138 \text { proteins identified; } 26 \text { proteins upregulated } \\
\text { and } 19 \text { proteins downregulated in 7-days MFGM } \\
\text { compared with colostrum MFGM; Upregulated } \\
\text { proteins: FABP and MUC1; Early developmental } \\
\text { shift in milk fat transport }\end{array}$ & [32] \\
\hline Holstein dairy cow milk & $\begin{array}{l}\text { Characterize variations in MFGM } \\
\text { proteome of multiparous and } \\
\text { primiparous dairy cows at four } \\
\text { timepoints postpartum (M1, M2, } \\
\text { M3, M4) }\end{array}$ & $\begin{array}{c}104 \text { shared proteins identified in each timepoint; } \\
\text { M1 proteome enriched in immune-associated } \\
\text { proteins and regulatory proteins; } 70 \% \text { of proteins } \\
\text { affected by milking; } 44 \% \text { of proteins affected } \\
\text { by parity; } 33 \% \text { of proteins affected by milking } \\
\text { and parity }\end{array}$ & [37] \\
\hline Jersey cow mature milk & $\begin{array}{l}\text { Characterize the effect of pasture } \\
\text { profile on the bovine } \\
\text { MFGM proteome }\end{array}$ & $\begin{array}{l}365 \text { proteins identified in the MFGM fraction; } \\
\text { Diet can alter the bovine MFGM proteome }\end{array}$ & [38] \\
\hline \multicolumn{4}{|c|}{ Other species } \\
\hline $\begin{array}{c}\text { Sarda dairy } \\
\text { sheep in mid-lactation }\end{array}$ & $\begin{array}{l}\text { Characterize the ovine MFGM } \\
\text { proteome }\end{array}$ & $\begin{array}{c}140 \text { total proteins identified; Major MFGM } \\
\text { proteins are the most abundant in ovine MFGM } \\
\text { proteome }\end{array}$ & [28] \\
\hline $\begin{array}{l}\text { Donkey colostrum and } \\
\text { mature milk }\end{array}$ & $\begin{array}{l}\text { Characterize MFGM proteins in at } \\
\text { two lactation periods }\end{array}$ & $\begin{array}{l}902 \text { and } 913 \text { MFGM proteins in donkey } \\
\text { colostrum and mature milk, respectively }\end{array}$ & [39] \\
\hline $\begin{array}{l}\text { Colostrum and mature } \\
\text { Xinong Saanen goat milk }\end{array}$ & $\begin{array}{l}\text { Investigate the variations between } \\
\text { goat colostrum and mature } \\
\text { MFGM proteome }\end{array}$ & $\begin{array}{l}543 \text { and } 858 \text { proteins in colostrum and mature } \\
\text { milk; } 394 \text { common proteins; Colostrum enriched } \\
\text { in protein processing in the ER; Mature milk } \\
\text { enriched in oxidative phosphorylation functions }\end{array}$ & [40] \\
\hline
\end{tabular}

\section{Comparative analyses}

Human and cow mature milk

Determine the differences in host defense proteomes

Proteins identified: human milk 268, bovine milk

269; 147 common proteins; More antimicrobial proteins in bovine milk; More Igs in human milk

Elucidate the proteome profile and biological activity of different species

Major proteins shared among species human milk

Characterize the MFGM proteome from different species

Investigate the MFGM proteins in human milk and three typically consumed milk in China

Identify the N-glycoproteins of the MFGM fractions from different species
520 proteins identified among all species, of which the most shared among all species

Major MFGM proteins conserved across species; Human MFGM proteome enriched in immunological factors and proteins involved in triglyceride and fatty acid catabolic process

Extended number of known glycosylation sites in the milk proteins from dairy animal species: $\mathrm{N}$-glycosylated proteins mostly related to the buffalo, yak, goat, camel,
baln and Jersey cows, horse, and human mature milk 
Table 1. Cont.

\begin{tabular}{|c|c|c|c|}
\hline Samples & Objective & Main Findings & Ref. \\
\hline Human and bovine colostrum & $\begin{array}{l}\text { Identify and analyze the } \\
\text { composition and expression } \\
\text { changes of colostrum MFGM } \\
\text { proteins in humans and bovines }\end{array}$ & $\begin{array}{l}411 \text { proteins identified from humans and } \\
\text { bovines; } 9 \text { upregulated and } 17 \text { downregulated in } \\
\text { humans compared to bovine; Upregulated } \\
\text { proteins in human colostrum mainly involved in } \\
\text { immune functions; Many of the differentially } \\
\text { expressed proteins involved in immune function }\end{array}$ & [44] \\
\hline Human and caprine milk & $\begin{array}{l}\text { Identify differences in MFGM } \\
\text { proteome of human and caprine } \\
\text { milk to evaluate nutritional } \\
\text { benefits of caprine milk for } \\
\text { infant's growth }\end{array}$ & $\begin{array}{l}128 \text { and } 42 \text { proteins in human and caprine } \\
\text { MFGM proteome, respectively; Higher content } \\
\text { of bioactive proteins in human than caprine } \\
\text { MFGM proteome; Caprine milk could be a } \\
\text { hypoallergenic alternative to newborns affected } \\
\text { by CMPA and without any chance of } \\
\text { breastfeeding }\end{array}$ & [45] \\
\hline $\begin{array}{l}\text { Human and bovine colostrum } \\
\text { and mature milk }\end{array}$ & $\begin{array}{l}\text { Compare MFGM } \\
\text { N-glycoproteomes among species } \\
\text { and lactation stages }\end{array}$ & $\begin{array}{l}362 \text { common proteins among human colostrum } \\
\text { and mature milk; } 155 \text { common proteins among } \\
\text { bovine colostrum and mature milk; Higher } \\
\text { variations among species than lactation stages }\end{array}$ & [46] \\
\hline $\begin{array}{l}\text { Holstein cow and Guanzhong } \\
\text { goat mature milk }\end{array}$ & $\begin{array}{l}\text { Compare whey and MFGM } \\
\text { proteins across species }\end{array}$ & $\begin{array}{c}\text { Major MFGM proteins shared across species; } \\
\text { 21\% goat MFGM proteins: metabolic processes; } \\
49 \% \text { cow MFGM proteins: } \\
\text { disease-associated pathways }\end{array}$ & [47] \\
\hline
\end{tabular}

Human and cow MFGM proteomes show several similarities. In terms of quantity, human and cow proteomes share the highest number of MFGM proteins and the highest linear correlation coefficient (166 proteins, $\mathrm{R}=0.71$ ) if compared to the MFGM proteome of goat (95 proteins, $\mathrm{R}=0.60$ ) and yak ( 76 proteins, $\mathrm{R}=0.62$ ). These data are also reported in Figure 1. In addition, BTN, ADPH, FABP and MUC1 are the major MFGM proteins and are shared among the two species $[22,29]$. These major proteins were identified as being the most abundant also in sheep MFGM proteome [28].

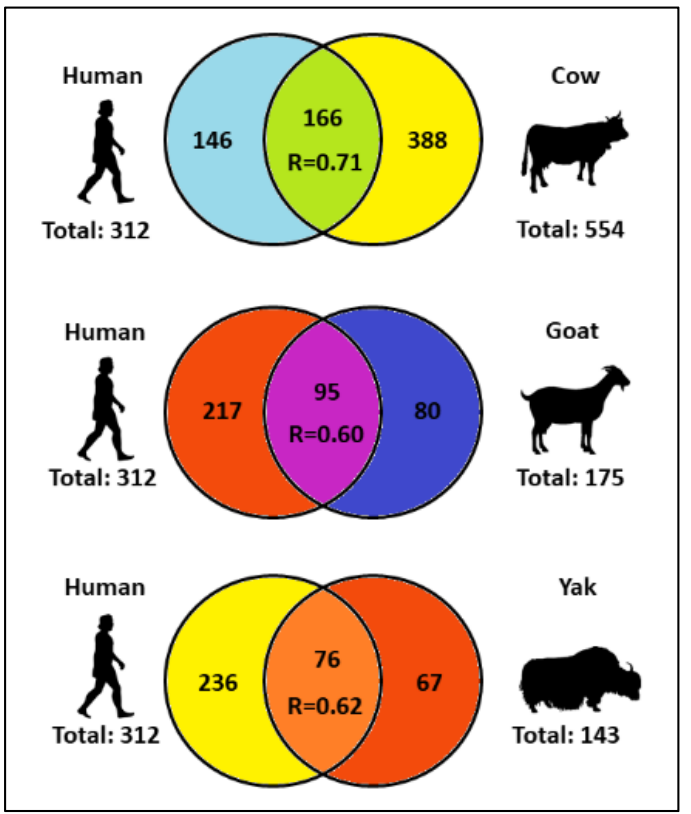

Figure 1. Number of individual and common milk fat globule membrane (MFGM) proteins in human, cow, goat and yak, and Pearson correlation coefficient (R) between the MFGM proteomes of human-cow, human-goat and human-yak. Adapted from Lu et al., 2016 [29]. 
Although there are quantitative similarities, human and cow MFGM proteomes show qualitative variations. In 2011, Hettinga and collaborators [27] observed slight variations in the number of proteins responsible for various molecular functions in human and cow MFGM proteomes (Table 2). The authors observed that the number of MFGM proteins related to the immune defense was comparable between cows (44) and humans (51). The cow's MFGM proteome was enriched in antibacterial proteins, named cathelicidins and mucins, related to innate immunity. Instead, the human MFGM proteome was enriched in four proteins involved in the mucosal immune system: IgA, CD14, lactoferrin and lysozyme [27]. IgA is the major isotype in the mucosal immune system and regulates the balance between commensal microorganisms and pathogens [48]. CD14 is part of the Tolllike receptor (TLR)- 4 complex and protects from the invasion of pathogens by activating the innate immune system. Lactoferrin and lysozyme are two antibacterial proteins with a role in the innate immune system. The significantly higher amounts of IgA and CD14 in human MFGM than bovine MFGM (500-fold and 4.7-fold increase, respectively) are explained by the different maturation of the immune system in human newborns and calves. Human and bovine colostral MFGM contain similar amounts of IgA and CD14. However, the concentration of IgA and CD14 decreases in bovine MFGM after the first days of lactation because calves are capable of producing intestinal IgA at 4 days of age, whereas the IgA concentration remains high in human MFGM because the intestine of human newborns is devoid of IgA and CD14 [27].

Table 2. Number of proteins in human and cow MFGM proteomes related to various molecular functions, listed according to the gene ontology (GO) annotation. Adapted from Hettinga et al. (2011) [27].

\begin{tabular}{cccc}
\hline Molecular Function & Human Proteins & Cow Proteins & Common Proteins \\
\hline Cell wall/adhesion & 21 & 17 & 8 \\
Coagulation & 3 & 7 & 3 \\
Cytoskeleton & 12 & 8 & 7 \\
Enzymes & 70 & 50 & 25 \\
Host defense & 44 & 51 & 33 \\
Protease inhibitors & 12 & 15 & 8 \\
Protein synthesis/chaperone & 11 & 9 & 4 \\
Signaling & 15 & 19 & 7 \\
Transport & 48 & 64 & 39 \\
Others & 32 & 29 & 13 \\
Total proteins & 268 & 269 & 147
\end{tabular}

It is well known that colostrum has a high content of immune-related proteins because it is essential in establishing the primitive acquired immune system in newborns [49]. As seen above [27], also colostral MFGM proteome contains a higher number of proteins related to the immune defense than milk of later phases of lactation [35,37,44]. A recent study [44] identified a total of 411 MFGM proteins in human and bovine colostrum. Of the 26 differentially expressed proteins, 9 were upregulated and 17 downregulated in humans if compared to bovine colostrum. These 9 proteins, such as neutrophil defensin 1 , protein S100, immunoglobulin K and lactadherin, were mostly involved in the innate and adaptive immune defense. The authors assessed that the MFGM proteome of human colostrum was more enriched in immune-related proteins than bovine colostrum [44]. The establishment of a proper immune system is related to the correct intestinal maturation in newborns. It was observed that calves fed with colostrum better established their immune system (higher levels of IgG and serum complement C3 and C4) than calves fed with transitional milk or bulk tank milk. Consequently, colostrum-fed calves showed better parameters of intestinal development (higher villus length and width, crypt depth and mucosal thickness) than the other two groups [50]. 
Regarding other species' MFGM proteome, some authors [45] compared human and goat MFGM proteomes. They identified 128 and 42 proteins in human and goat MFGM, respectively. Goat MFGM was richer in $\alpha$-s1-casein and lactadherin if compared to human MFGM. $\alpha$-casein is the major casein in bovine and goat milk, and the s1 subunit forms micellar complexes with calcium phosphate, thus enhancing calcium absorption. $\alpha$-s1casein is one of the allergens that cause cow's milk protein allergy (CMPA) in infants. Goat milk represents both a source of MFGM proteins [51] and also a hypoallergenic alternative to newborns affected by CMPA and without any chance of breastfeeding, as the amino acid sequences of bovine and goat $\alpha$-s1-casein are significantly different [45].

Besides the role of MFGM proteome in immunity, other bioactive functions of MFGM were investigated. Ji and co-authors [30] evaluated the antiproliferative effect of the MFGM fractions from five different mammalian species (yak, cow, goat, camel and buffalo) on the HT-29 human colon cancer cell line. All the MFGM fractions impaired the cell cycle, upregulated the apoptosis of HT-29 cells and reduced the mitochondrial membrane potential (an event related to apoptosis). The authors did not clarify which was the MFGM fraction responsible for the antiproliferative effect (proteins or polar lipids). However, this study compared the data of five different species and determined the antiproliferative function of MFGM. This is one of the few examples regarding the implementation of the comparative proteomics analyses on MFGM across species [30].

All the results reported above lead to three main conclusions: (i) the major MFGM proteins are shared among species, (ii) immune-related proteins are high in human colostral MFGM proteome and (iii) the molecular function and protein expression levels vary among species and different phases of lactation.

\section{Milk Minerals and Vitamins}

Milk and dairy products are crucial to the intake of minerals and vitamins. In fact, they provide $20-40 \%$ of total dietary intake of vitamins and $10-20 \%$ of total dietary intake of minerals in Western countries [52,53]. Table 3 reports the contribution of milk and dairy products to the intake of minerals and vitamins.

Table 3. Contribution of bovine milk and dairy products to the intake of minerals and vitamins. Data are expressed in \%. Adapted from Graulet (2014) [54] and Górska-Warsewicz et al. (2019) [55].

\begin{tabular}{cccccccccc}
\hline Minerals & Ca & P & Na & K & Mg & Fe & Zn & Cu & I \\
\hline Contribution (\%) & 55 & 25 & 7.3 & 12 & 11 & 3.5 & 14 & 5.8 & 9.1 \\
Vitamins & B1 & B2 & B5 & B12 & C & A & D & E & K \\
Contribution (\%) & $7-10$ & $28-39$ & 19 & 42 & $2-4$ & 11 & 5 & 2 & 1 \\
\hline
\end{tabular}

Most of the minerals are in the aqueous phase of milk (Table 4). However, the milk lipid fraction is a "natural solvent" for minerals and lipophilic vitamins; therefore, the localization in this fraction leads to an increase in their bioavailability and bioaccessibility [7,9]. Figure 2 shows the major minerals and lipophilic vitamins found in the milk lipid fraction.

An example for minerals is given by Pabón and Lönnerdal [56], who observed an increased iron bioavailability in rats fed a human milk fat-enriched diet. Human milk fat is richer in saturated fatty acids than infant formula, which is characterized by a higher content of unsaturated fatty acids (mostly from vegetable oils). The saturated fats of human milk modified the fatty acid composition of rats' intestinal mucosa and, therefore, increased iron absorption, iron retention and hemoglobin regeneration. These parameters were lower in rats fed with infant formula [56]. A further example for vitamins comes from the study of Hayes and collaborators [57]. These authors observed a higher absorption of vitamin $\mathrm{E}$ when microdispersed in milk, in comparison with the vitamin $\mathrm{E}$ in orange juice or in capsules. The increased bioavailability of vitamin E could be ascribed to the chemical features of milk fat. However, these findings need to be further addressed [58]. 


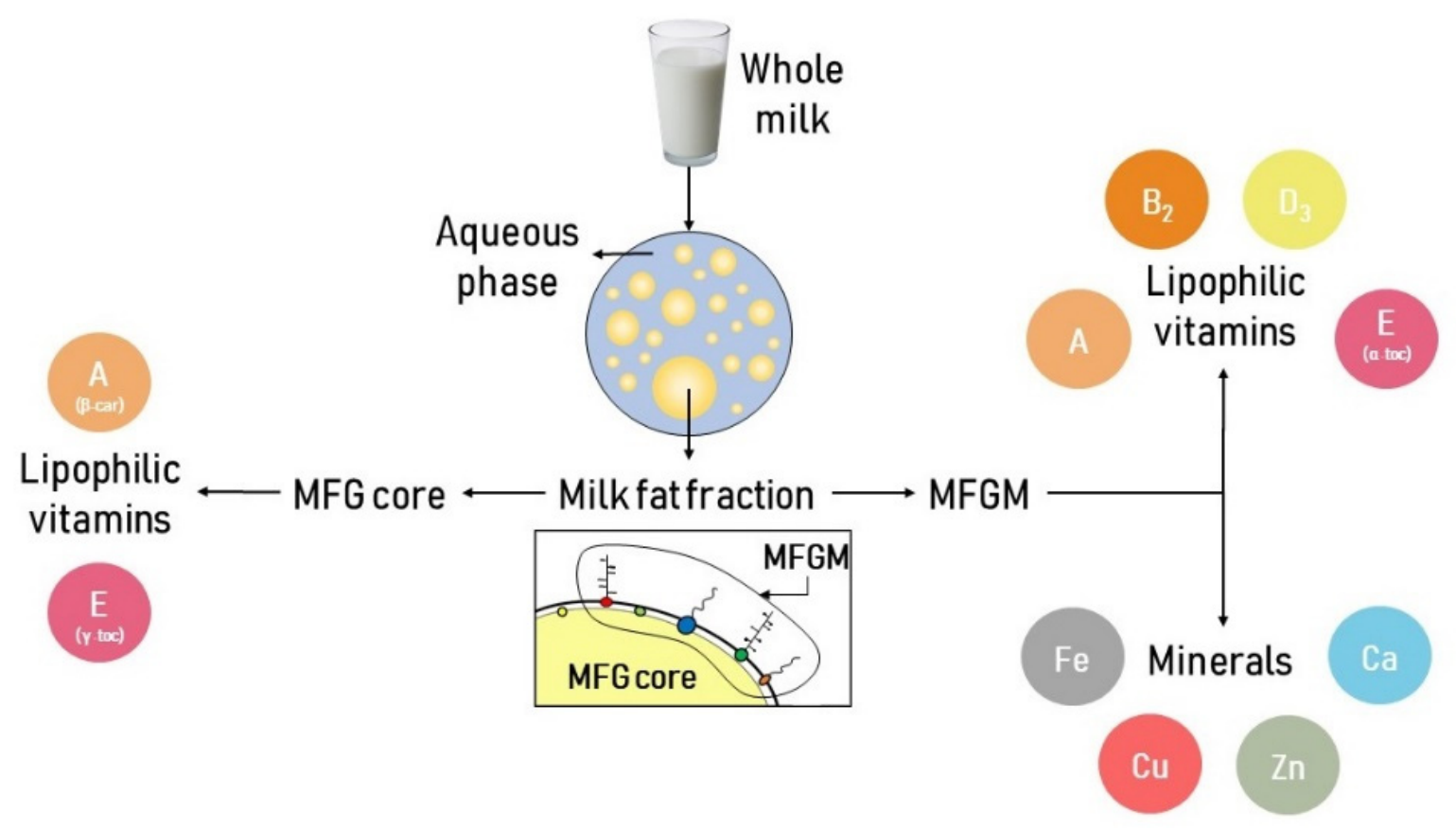

Figure 2. Schematic representation of the major minerals and lipophilic vitamins present in the milk lipid fraction.

\subsection{Minerals}

The major minerals in milk are calcium, magnesium, phosphorus, sodium, zinc and potassium [52]. The various minerals are distributed in milk according to their chemical characteristics. Several factors can influence the mineral content of milk, such as lactation stage (colostrum vs. mature milk) and animal diet's composition [59]. In this review we have focused on the mineral content of the milk lipid fraction, considering both macroelements and microelements.

In 1984, Fransson and Lönnerdal [60] reported that some minerals specific to human milk were associated with the milk lipid fraction. Regarding the distribution of the minerals in the milk lipid fraction, high amounts of iron (61\%), copper $(73 \%)$, zinc $(64 \%)$, calcium $(67 \%)$ and magnesium (71\%) were located in the outer bilayer of the MFGM, whereas a lower amount was associated with the inner monolayer membrane of the MFGM and then with the MFG core [60].

Subsequently, further studies evaluated the mineral content of the milk lipid fraction. Forty percent of iron content in human milk is found in the fat fraction, whereas in cow's milk iron content is similar, but the distribution in the milk lipid fraction is lower $(14 \%)$ (Table 4). Iron is bound to MFGM as cofactor of XDH/XO (xanthine dehydrogenase/xanthine oxidase), the major iron-binding protein [6,56]. Distribution of zinc is similar to iron. Indeed, $18 \%$ of total zinc in human milk is located in the MFGM bound to alkaline phosphatase, the major zinc-binding protein [60-62]. The zinc content is higher in cow's milk, but with a lower distribution in the milk lipid fraction (1\%) if compared to human milk lipid fraction (18\%) (Table 4 ). 
Table 4. Distribution of minerals in whole milk and in milk lipid fraction of human and cow's milk. Data from Zamberlin et al. (2011) [52], Mulder and Walstra (1974) [63], Fransson and Lonnerdal (1983) [64], Soliman (2005) [65], Walton and Flynn (2013) [66], Chassaing et al. (2016) [67] and Pietrzak-Fiećko and Kamelska-Sadowska (2020) [68].

\begin{tabular}{ccccc}
\hline \multirow{2}{*}{ Minerals } & \multicolumn{2}{c}{ Whole Milk } & \multicolumn{2}{c}{ Milk Lipid Fraction } \\
& Human & Cow & Human & Cow \\
\hline Calcium $(\mathbf{m g} / \mathbf{1 0 0} \mathbf{g})$ & $22-41$ & $107-133$ & $3.5-6.6(16 \%)$ & $0.2-0.4(1 \%)$ \\
Iron $(\boldsymbol{\mu g} / \mathbf{1 0 0} \mathbf{g})$ & $40-50$ & $30-70$ & $<20(40 \%)$ & $<1(14 \%)$ \\
Copper $(\boldsymbol{\mu g} / \mathbf{1 0 0} \mathbf{g})$ & $30-50$ & $12-17$ & $<8(15 \%)$ & $<0.3(2 \%)$ \\
Zinc $(\boldsymbol{\mu g} / \mathbf{1 0 0} \mathbf{g})$ & $145-165$ & $350-400$ & $<30(18 \%)$ & $<4(1 \%)$ \\
Magnesium $(\mathbf{m g} / \mathbf{1 0 0} \mathbf{g})$ & $3-3.5$ & $9-16$ & $0.06-0.07(2 \%)$ & - \\
Phosphorus $(\mathbf{m g} / \mathbf{1 0 0} \mathbf{g})$ & $12-17$ & $90-102$ & - & - \\
\hline
\end{tabular}

Calcium in milk is mainly associated with casein micelles. However, $16 \%$ of the total milk calcium is found in the human milk lipid fraction. Of this amount, $67 \%$ is located in the MFGM [62]. As well as zinc, calcium content is higher in cow's milk than in human milk (120 vs. $30 \mathrm{mg} / 100 \mathrm{~g}$, respectively). However, calcium content in the milk lipid fraction is significantly lower in cow $(1 \%)$ than in human $(16 \%)$ milk (Table 4$)$. Although the diameter of MFGs is similar between human and cow's milk and ranges between 0.1 and $15 \mu \mathrm{m}$, calcium content in milk is correlated to MFGs' size. Smaller MFGs are characterized by a higher MFGM and calcium content than larger MFGs. In fact, MFGM content is inversely proportional to the size of MFGs (because of the surface area: volume ratio), and calcium content is mainly associated with MFGM than MFG core [69].

Finally, literature data reported that the intake of milk and dairy products is responsible for $15-40 \%$ intake of magnesium [70]. However, about $98 \%$ of magnesium is found in the skim milk phase [71]. This is the reason why magnesium content in the milk lipid fraction has received little consideration in the literature, apart from the case of Fransson and Lonnerdal [60].

It is important to underline that milk usually undergoes several industrial processes before consumption. For example, heating can affect the nutritional value and the content of micronutrients of milk. However, raw milk can be contaminated with pathogens. Therefore, heating milk is thus necessary to avoid this risk and to increase the shelf-life of milk [72]. For what concerns minerals, their content is unaffected by heating because minerals are both very heat-stable, and in milk they are usually bound with other components, such as enzymes [73]. The only exception is iron. As seen in Section 3.2, iron is bound to MFGM as a cofactor of $\mathrm{XDH} / \mathrm{XO}$. This binding was validated observing a decreased amount of iron in the MFGM in response to heating, in particular from $110 \mathrm{ppm}$ in the MFGM unheated cream $\left(50^{\circ} \mathrm{C}\right)$ to $20 \mathrm{ppm}$ in MFGM heated cream $\left(80^{\circ} \mathrm{C}\right)$. Heating induces the conversion of the dehydrogenase form of the enzyme $(\mathrm{XDH})$ to the oxidase one $(\mathrm{XO})$, thus causing the release of iron from $\mathrm{XDH} / \mathrm{XO}$ [74].

To summarize, the milk lipid fraction contains mainly iron, copper, zinc and calcium, even though some of these minerals are present in trace amounts. Since this fraction is rich in bioactive polar lipids and proteins, and it also contains certain amounts of minerals, the inclusion into value-added products could be beneficial.

\subsection{Vitamins}

Milk contains both hydrophilic and lipophilic vitamins. Hydrophilic vitamins are vitamins $C$ and those belonging to the $B$ family, whereas lipophilic vitamins are $A, D, E$ and $\mathrm{K}$. According to their chemical features, they are distributed either in the aqueous phase or in the milk lipid fraction [2,55]. The milk lipid fraction is a major source of lipophilic vitamins. The content of lipophilic vitamins in milk fat is related to the total milk fat content and composition. Indeed, altering the total milk lipid profile changes the content of lipophilic vitamins. The distribution among MFG core and MFGM depends on 
the chemical characteristics of each vitamin [9]. Table 5 reports the content of lipophilic vitamins in human and cow milk lipid fractions.

Table 5. Content of lipophilic vitamins in human and cow milk. Data from Baldi and Pinotti (2008) [9], Öste et al. (1997) [75], Park (2007) [76], Fantuz et al. (2016) [77] and Biadala and Konieczny (2018) [78].

\begin{tabular}{ccc}
\hline Vitamins & Human Milk & Cow's Milk \\
\hline Vitamin A + all-trans- $\beta$-carotene $(\mathbf{m g} / \mathbf{1 0 0} \mathbf{g})$ & $0.05-0.06$ & 0.04 \\
Vitamin D $(\boldsymbol{\mu g} / \mathbf{1 0 0} \mathbf{g})$ & $0.04-0.07$ & $0.05-0.06$ \\
Vitamin E $(\mathbf{m g} / \mathbf{1 0 0} \mathbf{g})$ & $0.24-0.28$ & $0.10-0.13$ \\
Vitamin K $(\boldsymbol{\mu g} / \mathbf{1 0 0} \mathbf{g})$ & $0.3-0.5$ & 1.1 \\
\hline
\end{tabular}

Vitamin A in milk is mainly present as retinol esters. The esters of retinol derive from dietary intake and from the esterification of retinol in the mammary gland. Vitamin $\mathrm{A}$ is associated with the milk lipid fraction and especially to the MFGM more than the MFG core [79]. Zahar and Smith [80] observed that the vitamin A content is inversely proportional to the size of the MFGs; therefore, vitamin A concentration is higher in smaller than in larger MFGs (Table 6). Since the content of MFGM is inversely proportional to the MFGs size, they demonstrated that most of the vitamin A content is in the MFGM, as observed also by Jensen and Nielsen $[79,80]$. Regarding the sources of vitamin A, the authors observed a higher content of vitamin A in buttermilk than in butter oil obtained from the same cream (Table 6) [80]. This is a crucial result because buttermilk is widely recognized as the most important source of MFGM among dairy products and industrial by-products $[81,82]$.

Table 6. Concentration of retinol in larger and smaller MFGs (obtained from the same cream) expressed as \% retinol/g of fat of buttermilk or butter oil compared with retinol content in whole milk. Data are expressed as mean \pm SEM. Values with different superscripts $(a, b)$ are significantly different $(p<0.05)$. Data from Zahar and Smith (1995) [80].

\begin{tabular}{ccc}
\hline Source of Vitamin A & Cream with Larger MFGs & Cream with Smaller MFGs \\
\hline Buttermilk & $98.13^{\mathrm{a}} \pm 2.20$ & $103.85^{\mathrm{a}} \pm 2.18$ \\
Butter oil & $90.40^{\mathrm{b}} \pm 1.84$ & $87.83^{\mathrm{b}} \pm 0.69$ \\
\hline
\end{tabular}

In addition, the milk lipid fraction also contains carotenes. The main carotene compound in milk is all-trans- $\beta$-carotene, which is a precursor of vitamin A [5]. The processes of $\beta$-carotene absorption and conversion to vitamin A produce losses; therefore, $6 \mathrm{mg}$ of $\beta$-carotene is required to obtain $1 \mathrm{mg}$ of retinol equivalent [9]. The symmetrical structure and the cleavage efficacy of all-trans- $\beta$-carotene makes it the most efficient provitamin A carotenoid [83]. $\beta$-carotene is a lipophilic compound and it is located in the milk lipid fraction, more in the MFG than in the MFGM [84]. This was demonstrated by Patton and collaborators, who separated MFGs from MFGM through butter churning and observed that the $\beta$-carotene content was higher in the MFG sample. This content was comparable to that found in the total milk lipid fraction [85]. The same result was also obtained by Jensen and Nielsen [79].

Vitamin $\mathrm{E}$ is a family of lipophilic compounds known for their antioxidant activity. The vitamin E family is divided into two classes, namely tocotrienols and tocopherols. $\alpha$-tocopherol is the most active form of vitamin $\mathrm{E}$ in the organism [86]. As for vitamin A, the $\alpha$-tocopherol content in milk depends on the total milk fat content. Indeed, an increase of $1 \mathrm{~g}$ in total milk lipids causes an increase of $17 \mathrm{mg}$ of $\alpha$-tocopherol [9]. This compound is mostly located in the MFGM, where it exerts an antioxidant function, thus protecting MFGM phospholipids from lipid peroxidation. $\gamma$-tocopherol is another compound of the vitamin E family. Unlike $\alpha$-tocopherol, $\gamma$-tocopherol is mainly present in the MFG core and not in the MFGM. This feature makes it less bioavailable and less bioaccessible than $\alpha$-tocopherol $[79,87]$. 
In addition, several authors highlighted the presence of vitamin $\mathrm{D}$ in the milk lipid fraction. Vitamin D is a family of liposoluble vitamins, and the prevalent form in the milk lipid fraction is vitamin $\mathrm{D}_{3}$ (cholecalciferol). Vitamin $\mathrm{D}_{3}$ is indirectly associated with MFGM as a result of the binding between vitamin $D_{3}$ and $\beta$-lactoglobulin $A$. Indeed, $\beta$-lactoglobulin A directly binds MFGM in response to heat treatments and, therefore, acts as a "bridge" for the association between MFGM and vitamin $\mathrm{D}_{3}[5,88,89]$.

Finally, the content of riboflavin (vitamin $B_{2}$ ) in milk is peculiar because of its hydrophilic nature. Riboflavin is a component of flavin mononucleotide (FMN) and flavin adenine dinucleotide (FAD), two coenzymes that are involved in metabolic pathways such as energy production and cell metabolism. The content of riboflavin in cow's milk is $160-170 \mu \mathrm{g} / 100 \mathrm{~g}$, whereas in human milk it is $20 \mu \mathrm{g} / 100 \mathrm{~g}$, which is significantly lower $[75,76,90]$. Riboflavin is a hydrophilic vitamin, and $67 \%$ of the total content is in the whey fraction. However, $6 \%$ is also found in the fat fraction. In particular, the majority of riboflavin in the fat fraction is associated with MFGM proteins ( $92 \%)$, probably bound to the MFGM flavoprotein xanthine oxidase (XO) [90].

Regarding the effect of heating on the milk vitamin content, there is a distinction between hydrophilic and lipophilic vitamins. The levels of the hydrophilic vitamins $B_{1}, B_{12}$ and $C$ decrease by $10-20 \%$ after pasteurization. Instead, vitamin $B_{2}$ is unaffected, and this is valid also for the lipophilic vitamins. Indeed, vitamins A, D, E and $\beta$-carotene appear to suffer no loss after pasteurization or microwave heating [73,91].

To summarize, the main lipophilic vitamins in milk are present either in the MFGM or in the MFG core. Vitamin A, vitamin $\mathrm{D}_{3}, \alpha$-tocopherol and riboflavin are mainly located in the MFGM, whereas $\beta$-carotene and $\gamma$-tocopherol are mainly located in the MFG core.

\section{Prospective Opportunities for the Future}

In recent years proteomics techniques have been adopted to expand and deepen the knowledge about the MFGM proteome. The MFGM proteome of each species' milk is enriched in certain proteins. The different isoforms and molecular functions of specific MFGM proteins from certain animal species could be exploited to design products that respond to specific clinical needs. The well-established higher content of immune-related proteins in MFGM of colostrum across all species could be used to enhance the immune functions of specific subjects by potentially decreasing the number of infective episodes in newborns [80]. Moreover, the human MFGM proteome is enriched in proteins capable of protecting the integrity of the mucosal immune system, thus decreasing the risk of pathogen adhesion and infection [27]. Among the MFGM bioactive proteins, glycoproteins such as MUC1, PAS III, PAS 6/7 and CD36 showed higher resistance to endogenous proteases involved in the digestive process, if compared with non-glycosylated MFGM proteins $[19,20]$. This means that MFGM glycoproteins are capable of reaching the intestinal epithelium and maintaining their integrity. The industrial exploitation of these results could lead to the design of glycoprotein-rich MFGM mixtures that exert an antiadhesive effect at the intestinal mucosal level [92] or an antiviral effect, for example against rotavirus infection [82]. In addition, MFGM proteins can be used to positively modulate the bacterial population of the gut microbiota $[92,93]$.

The idea of using specific MFGM proteins (or other components) to enrich infant formulas is another field of application. Nowadays, standard infant formulas are cow milkbased [94]. Although infant formulas mimic the composition of human breast milk, this latter contains bioactive compounds such as immunoglobulins, enzymes and hormones that are not included in standard infant formulas [95]. The supplementation of standard infant formulas with MFGM proteins represents an attempt to better achieve the bioactivity of human breast milk by infant formulas. Several studies based on the administration of a MFGM protein-enriched infant formula to infants showed promising results [14,96,97]. The experimental formulas could sustain the establishment of a proper immune system in infants and therefore reduce episodes of diarrhea [96] and also sustain the cognitive performance of infants, resembling the results obtained by breastfed infants [14]. However, 
further research will increase the knowledge on the MFGM proteome and on its potential inclusion in infant formulas.

Recently, the isolation and separation procedures of MFGM moved forward [98,99], increasing the possibility to isolate and separate specific bioactive lipid or protein components. The human milk lipid fraction has a higher content of minerals if compared to cow's milk. This suggests that the human milk lipid fraction is more effective as being a "natural solvent" for micronutrients, especially for minerals. This feature could be crucial to face new necessities, such as deficient conditions regarding the intake of certain minerals or vitamins.

The innovative element of this application of the milk lipid fraction lies in the fact that the bioactive role of micronutrients would be associated with the bioactive role of MFGM phospholipids and the MFGM proteome. The affinity between MFMG and vitamins can be exploited to design and produce stable delivery systems for molecules. Examples are the liposomes synthesized using MFGM phospholipids and carrying bioactive compounds such as $\alpha$-tocopherol. These liposomes showed high encapsulation efficiency $(77 \%)$ and structural endurance, in line with previous results [100].

\section{Conclusions}

The complex architecture of MFGs ensures a stable dispersion for the bioactive compounds of milk. The MFGM proteome varies among species but retains its antimicrobial and antiadhesive properties. Further, the MFGM proteome can act as a scaffold for many of the micronutrients such as minerals and lipophilic vitamins, which can indirectly join the milk lipid fraction. The presence of minerals and lipophilic vitamins enhances the bioactive role of the milk lipid fraction.

To conclude, in this review we have provided a characterization of the variations and similarities of the MFGM proteome of different species' milk and the potential applications of the MFGM proteome. In addition, we revised the data about the micronutrient content of the milk lipid fraction of human and cow's milk. Further research is needed firstly to clarify the exact content of micronutrients in MFGs, then to implement this knowledge for the design of value-added products.

Author Contributions: Conceptualization and literature review, M.M. and L.P.; writing-original draft preparation, M.M.; writing—review and editing, D.C., S.M., C.G., M.M. and L.P.; supervision, L.P., D.C., C.G. and A.B. All authors have read and agreed to the published version of the manuscript.

Funding: This research received no external funding.

Institutional Review Board Statement: Not applicable.

Informed Consent Statement: Not applicable.

Data Availability Statement: Not applicable.

Acknowledgments: This work was developed as part of the PhD program in Nutrition Sciences, University of Milan.

Conflicts of Interest: The authors declare no conflict of interest.

\section{References}

1. Park, Y.W. Overview of bioactive components in milk and dairy products. In Bioactive Components in Milk and Dairy Products, 1st ed.; Park, Y.W., Ed.; Wiley-Blackwell Publishers: Oxford, UK, 2009; pp. 3-14.

2. Gaucheron, F. Milk and dairy products: A unique micronutrient combination. J. Am. Coll. Nutr. 2011, 30, 400S-409S. [CrossRef]

3. Spitsberg, V.L. Invited review: Bovine milk fat globule membrane as a potential nutraceutical. J. Dairy Sci. 2005, 88, 2289-2294. [CrossRef]

4. Arranz, E.; Corredig, M. Invited review: Milk phospholipid vesicles, their colloidal properties, and potential as delivery vehicles for bioactive molecules. J. Dairy Sci. 2017, 100, 4213-4222. [CrossRef] [PubMed]

5. Bernard, L.; Bonnet, M.; Delavaud, C.; Delosiere, M.; Ferlay, A.; Fougere, H.; Graulet, B. Milk Fat Globule in Ruminant: Major and Minor Compounds, Nutritional Regulation and Differences Among Species. Eur. J. Lipid Sci. Tech. 2018, 120, 1700039. [CrossRef]

6. Lee, H.; Padhi, E.; Hasegawa, Y.; Larke, J.; Parenti, M.; Wang, A.; Hernell, O.; Lönnerdal, B.; Slupsky, C. Compositional Dynamics of the Milk Fat Globule and Its Role in Infant Development. Front. Pediatr. 2018, 6, 313. [CrossRef] [PubMed] 
7. German, J.B.; Dillard, C.J. Composition, structure and absorption of milk lipids: A source of energy, fat-soluble nutrients and bioactive molecules. Crit. Rev. Food Sci. Nutr. 2006, 46, 57-92. [CrossRef]

8. Koletzko, B. Human Milk Lipids. Ann. Nutr. Metab. 2016, 69, 28-40. [CrossRef] [PubMed]

9. Baldi, A.; Pinotti, L. Lipophilic microconstituents of milk. Adv. Exp. Med. Biol. 2008, 606, 109-125.

10. Bernard, L.; Leroux, C.; Chilliard, Y. Nutritional regulation of mammary lipogenesis and milk fat in ruminant: Contribution to sustainable milk production. Rev. Colomb. Cienc. Pecu. 2013, 26, 292-302.

11. Bionaz, M.; Loor, J.J. Gene networks driving bovine milk fat synthesis during the lactation cycle. BMC Genom. 2008, 9, 366. [CrossRef]

12. Manoni, M.; Di Lorenzo, C.; Ottoboni, M.; Tretola, M.; Pinotti, L. Comparative Proteomics of Milk Fat Globule Membrane (MFGM) Proteome across Species and Lactation Stages and the Potentials of MFGM Fractions in Infant Formula Preparation. Foods 2020, 9, 1251. [CrossRef]

13. Fox, P.F. Advanced Dairy Chemistry, 3rd ed.; Fox, P.F., McSweeney, P.L.H., Eds.; Chapman \& Hall: London, UK; New York, NY, USA, 1992.

14. Timby, N.; Domellöf, E.; Hernell, O.; Lönnerdal, B.; Domellöf, M. Neurodevelopment, nutrition, and growth until 12 mo of age in infants fed a low-energy, low-protein formula supplemented with bovine milk fat globule membranes: A randomized controlled trial. Am. J. Clin. Nutr. 2014, 99, 860-868. [CrossRef]

15. Gallier, S.; Vocking, K.; Post, J.A.; Van De Heijning, B.; Acton, D.; van der Beek, E.M.; Van Baalen, T. A novel infant milk formula concept: Mimicking the human milk fat globule structure. Colloid Surf. B 2015, 136, 329-339. [CrossRef] [PubMed]

16. Davoodi, S.H.; Shahbazi, R.; Esmaeili, S.; Sohrabvandi, S.; Mortazavian, A.; Jazayeri, S.; Taslimi, A. Health-Related Aspects of Milk Proteins. Iran. J. Pharm. Res. 2016, 15, 573-591. [PubMed]

17. Giromini, C.; Cheli, F.; Rebucci, R.; Baldi, A. Invited review: Dairy proteins and bioactive peptides: Modeling digestion and the intestinal barrier. J. Dairy Sci. 2019, 102, 929-942. [CrossRef] [PubMed]

18. Giromini, C.; Lovegrove, J.A.; Givens, D.I.; Rebucci, R.; Pinotti, L.; Maffioli, E.; Tedeschi, G.; Sundaram, T.S.; Baldi, A. In vitrodigested milk proteins: Evaluation of angiotensin-1-converting enzyme inhibitory and antioxidant activities, peptidomic profile, and mucin gene expression in HT29-MTX cells. J. Dairy Sci. 2019, 102, 10760-10771. [CrossRef]

19. Ye, A.; Cui, J.; Singh, H. Proteolysis of milk fat globule membrane proteins during in vitro gastric digestion of milk. J. Dairy Sci. 2011, 94, 2762-2770. [CrossRef] [PubMed]

20. Le, T.T.; Van de Wiele, T.; Do, T.N.H.; Debyser, G.; Struijs, K.; Devreese, B.; Dewettinck, K.; Van Camp, J. Stability of milk fat globule membrane proteins toward human enzymatic gastrointestinal digestion. J. Dairy Sci. 2012, 95, 2307-2318. [CrossRef] [PubMed]

21. Thum, C.; Young, W.; Montoya, C.A.; Roy, N.C.; McNabb, W.C. In vitro Fermentation of Digested Milk Fat Globule Membrane from Ruminant Milk Modulates Piglet Ileal and Caecal Microbiota. Front. Nutr. 2020, 7, 91. [CrossRef]

22. Mather, I.H. A review and proposed nomenclature for major proteins of the milk-fat globule membrane. J. Dairy Sci. 2000, 83, 203-247. [CrossRef]

23. Brink, L.R.; Herren, A.W.; McMillen, S.; Fraser, K.; Agnew, M.; Roy, N.; Lönnerdal, B. Omics analysis reveals variations among commercial sources of bovine milk fat globule membrane. J. Dairy Sci. 2020, 103, 3002-3016. [CrossRef]

24. Rhodes, D.A.; Reith, W.; Trowsdale, J. Regulation of immunity by butyrophilins. Annu. Rev. Immunol. 2016, 34, 151-172. [CrossRef]

25. Struijs, K.; Van de Wiele, T.; Le, T.T.; Debyser, G.; Dewettinck, K.; Devreese, B.; Van Camp, J. Milk fat globule membrane glycoproteins prevent adhesion of the colonic microbiota and result in increased bacterial butyrate production. Int. Dairy J. 2013, 32, 99-109. [CrossRef]

26. Cavaletto, M.; Giuffrida, M.G.; Conti, A. The proteomic approach to analysis of human milk fat globule membrane. Clin. Chim. Acta. 2004, 347, 41-48. [CrossRef] [PubMed]

27. Hettinga, K.; van Valenberg, H.; de Vries, S.; Boeren, S.; van Hooijdonk, T.; van Arendonk, J.; Vervoort, J. The host defense proteome of human and bovine milk. PLoS ONE 2011, 6, e19433. [CrossRef]

28. Pisanu, S.; Ghisaura, S.; Pagnozzi, D.; Biosa, G.; Tanca, A.; Roggio, T.; Uzzau, S.; Addis, M.F. The sheep milk fat globule membrane proteome. J. Proteom. 2011, 74, 350-358. [CrossRef] [PubMed]

29. Lu, J.; Wang, X.; Zhang, W.; Liu, L.; Pang, X.; Zhang, S.; Lv, J. Comparative proteomics of milk fat globule membrane in different species reveals variations in lactation and nutrition. Food Chem. 2016, 196, 665-672. [CrossRef]

30. Ji, X.; Xu, W.; Cui, J.; Ma, Y.; Zhou, S. Goat and buffalo milk fat globule membranes exhibit better effects at inducing apoptosis and reduction the viability of HT-29 cells. Sci. Rep. 2019, 9, 2577. [CrossRef] [PubMed]

31. Ballard, O.; Morrow, A.L. Human milk composition: Nutrients and bioactive factors. Pediatr. Clin. N. Am. 2013, 60, 49-74. [CrossRef] [PubMed]

32. Reinhardt, T.A.; Lippolis, J.D. Developmental changes in the milk fat globule membrane proteome during the transition from colostrum to milk. J. Dairy Sci. 2008, 91, 2307-2318. [CrossRef]

33. Fortunato, D.; Giuffrida, M.G.; Cavaletto, M.; Garoffo, L.P.; Dellavalle, G.; Napolitano, L.; Giunta, C.; Fabris, C.; Bertino, E.; Coscia, A.; et al. Structural proteome of human colostral fat globule membrane proteins. Proteomics 2003, 3, 897-905. [CrossRef] [PubMed] 
34. Liao, Y.; Alvarado, R.; Phinney, B.; Lönnerdal, B. Proteomic characterization of human milk fat globule membrane proteins during a 12 month lactation period. J. Proteome Res. 2011, 10, 3530-3541. [CrossRef]

35. Yang, M.; Deng, W.; Cao, X.; Wang, L.; Yu, N.; Zheng, Y.; Wu, J.; Wu, R.; Yue, X. Quantitative Phosphoproteomics of Milk Fat Globule Membrane in Human Colostrum and Mature Milk: New Insights into Changes in Protein Phosphorylation during Lactation. J. Agric. Food Chem. 2020, 68, 4546-4556. [CrossRef] [PubMed]

36. Reinhardt, T.A.; Lippolis, J.D. Bovine milk fat globule membrane proteome. J. Dairy Res. 2006, 73, 406-416. [CrossRef] [PubMed]

37. Honan, M.C.; Fahey, M.J.; Fischer-Tlustos, A.J.; Steele, M.A.; Greenwood, S.L. Shifts in the Holstein dairy cow milk fat globule membrane proteome that occur during the first week of lactation are affected by parity. J. Anim. Sci. Biotechnol. 2020, 11, 81. [CrossRef]

38. Scuderi, R.A.; Lam, Y.-W.; Ebenstein, D.B.; Tacoma, R.; Cersosimo, L.M.; Kraft, J.; Brito, A.F.; Greenwood, S.L. Comparative analysis of the skim milk and milk fat globule membrane proteomes produced by Jersey cows grazing pastures with different plant species diversity. J. Dairy Sci. 2020, 3, 7498-7508. [CrossRef]

39. Li, W.; Li, M.; Cao, X.; Yang, M.; Han, H.; Kong, F.; Yue, X. Quantitative proteomic analysis of milk fat globule membrane (MFGM) proteins from donkey colostrum and mature milk. Food Funct. 2019, 10, 4256-4268. [CrossRef]

40. Sun, Y.; Wang, C.; Sun, X.; Jiang, S.; Guo, M. Characterization of the milk fat globule membrane proteome in colostrum and mature milk of Xinong Saanen goats. J. Dairy Sci. 2020, 103, 3017-3024. [CrossRef]

41. Spertino, S.; Cipriani, V.; De Angelis, C.; Giuffrida, M.G.; Marsano, F.; Cavaletto, M. Proteome profile and biological activity of caprine, bovine and human milk fat globules. Mol. Biosyst. 2012, 8, 967-974. [CrossRef]

42. Yang, Y.; Zheng, N.; Zhao, X.W.; Zhang, Y.D.; Han, R.W.; Ma, L.; Zhao, S.; Li, S.; Guo, T.; Wang, J. Proteomic characterization and comparison of mammalian milk fat globule proteomes by iTRAQ analysis. J. Proteom. 2015, 116, 34-43. [CrossRef]

43. Yang, Y.; Zheng, N.; Wang, W.; Zhao, X.; Zhang, Y.; Han, R.; Ma, L.; Zhao, S.; Li, S.; Guo, T.; et al. N-glycosylation proteomic characterization and cross-species comparison of milk fat globule membrane proteins from mammals. Proteomics 2016, 16, 2792-2800. [CrossRef] [PubMed]

44. Yang, M.; Peng, X.; Wu, J.; Wu, R.; Liu, B.; Ye, W.; Xu, X.; Yue, X. Differential proteomic analysis of milk fat globule membrane proteins in human and bovine colostrum by iTRAQ-coupled LC-MS/MS. Eur. Food Res. Technol. 2017, 243, 901-912. [CrossRef]

45. Juvarajah, T.; Wan-Ibrahim, W.I.; Ashrafzadeh, A.; Othman, S.; Hashim, O.H.; Fung, S.Y.; Abdul-Rahman, P.S. Human Milk Fat Globule Membrane Contains Hundreds of Abundantly Expressed and Nutritionally Beneficial Proteins That Are Generally Lacking in Caprine Milk. Breastfeed. Med. 2018, 13, 631-637. [CrossRef]

46. Cao, X.; Zheng, Y.; Wu, S.; Yang, N.; Yue, X. Characterization and comparison of milk fat globule membrane N-glycoproteomes from human and bovine colostrum and mature milk. Food Funct. 2019, 10, 5046-5058. [CrossRef]

47. Sun, Y.; Wang, C.; Sun, X.; Guo, M. Comparative Proteomics of Whey and Milk Fat Globule Membrane Proteins of Guanzhong Goat and Holstein Cow Mature Milk. J. Food Sci. 2019, 84, 244-253. [CrossRef] [PubMed]

48. Li, Y.; Jin, L.; Chen, T. The effects of secretory IgA in the mucosal immune system. Biomed. Res. Int. 2020, 2020, 2032057. [CrossRef] [PubMed]

49. Stelwagen, K.; Carpenter, E.; Haigh, B.; Hodgkinson, A.; Wheeler, T.T. Immune components of bovine colostrum and milk. J. Anim. Sci. 2009, 87, 3-9. [CrossRef]

50. Yang, M.; Zou, Y.; Wu, Z.H.; Li, S.L.; Cao, Z.J. Colostrum quality affects immune system establishment and intestinal development of neonatal calves. J. Dairy Sci. 2015, 98, 7153-7163. [CrossRef] [PubMed]

51. Gallier, S.; Tolenaars, L.; Prosser, C. Whole Goat Milk as a Source of Fat and Milk Fat Globule Membrane in Infant Formula. Nutrients 2020, 12, 3486. [CrossRef]

52. Zamberlin, Š.; Antunac, N.; Havranek, J.; Samaržija, D. Mineral elements in milk and dairy products. Mljekarstvo 2011, 62, 111-125.

53. Melse-Boonstra, A. Bioavailability of Micronutrients from Nutrient-Dense Whole Foods: Zooming in on Dairy, Vegetables, and Fruits. Front. Nutr. 2020, 7, 101. [CrossRef]

54. Graulet, B. Ruminant milk: A source of vitamins in human nutrition. Anim. Front. 2014, 4, 24-30. [CrossRef]

55. Górska-Warsewicz, H.; Rejman, K.; Laskowski, W.; Czeczotko, M. Milk and Dairy Products and Their Nutritional Contribution to the Average Polish Diet. Nutrients 2019, 11, 1771. [CrossRef]

56. Pabón, M.L.; Lönnerdal, B. Effects of Type of Fat in the Diet on Iron Bioavailability Assessed in Suckling and Weanling Rats. J. Trace Elem. Med. Biol. 2001, 15, 18-23. [CrossRef]

57. Hayes, K.C.; Pronczuk, A.; Perlman, D. Vitamin E in fortified cow milk uniquely enriches human plasma lipoproteins. Am. J. Clin. Nutr. 2001, 74, 211-218. [CrossRef] [PubMed]

58. Borel, P.; Preveraud, D.; Desmarchelier, C. Bioavailability of vitamin E in humans: An update. Nutr. Rev. 2013, 71, 319-331. [CrossRef] [PubMed]

59. Cashman, K.D. Milk minerals (including trace elements) and bone health. Int. Dairy J. 2006, 16, 1389-1398. [CrossRef]

60. Fransson, G.B.; Lönnerdal, B. Iron, copper, zinc, calcium, and magnesium in human milk fat. Am. J. Clin. Nutr. 1984, 39, 185-189. [CrossRef]

61. Bingham, E.W.; Malin, E.L. Alkaline phosphatase in the lactating bovine mammary gland and the milk fat globule membrane. Release by phosphatidylinositol-specific phospholipase C. Comp. Biochem. Physiol. B 1992, 102, 213-218. [CrossRef] 
62. Lönnerdal, B. Effects of milk and milk components on calcium, magnesium, and trace element absorption during infancy. Physiol. Rev. 1997, 77, 643-669. [CrossRef] [PubMed]

63. Mulder, H.; Walstra, P. The milk fat globule Emulsion Science as Applied to Milk Products and Comparable Foods. In Commonwealth Agricultural Bureau; Farnham Royal and Centre for Agricultural Publishing and Documentation: Wageningen, The Netherlands, 1974.

64. Fransson, G.B.; Lonnerdal, B. Distribution of trace elements and minerals in human and cow's milk. J. Pediatr. 1983, 17, 912-915. [CrossRef]

65. Soliman, Z.A. Comparison of chemical and mineral content of milk from human, cow, buffalo, camel and goat in Egypt. Egypt J. Hosp. Med. 2005, 21, 116-130.

66. Walton, J.; Flynn, A. Nutritional adequacy of diets containing growing up milks or unfortified cow's milk in Irish children (aged 12-24 months). Food Nutr. Res. 2013, 57, 21836. [CrossRef] [PubMed]

67. Chassaing, C.; Sibra, C.; Verbič, J.; Harstad, O.M.; Golecký, J.; Martin, B.; Ferlay, A.; Constant, I.; Delavaud, C.; Hurtaud, C.; et al. Mineral, vitamin A and fat composition of bulk milk related to European production conditions throughout the year. Dairy Sci. Technol. 2016, 96, 715-733. [CrossRef]

68. Pietrzak-Fiećko, R.; Kamelska-Sadowska, A.M. The Comparison of Nutritional Value of Human Milk with Other Mammals' Milk. Nutrients 2020, 12, 1404. [CrossRef]

69. Couvreur, S.; Hurtaud, C. Relationships between milks differentiated on native milk fat globule characteristics and fat, protein and calcium compositions. Animal 2017, 11, 507-518. [CrossRef]

70. Cazzola, R.; Della Porta, M.; Manoni, M.; Iotti, S.; Pinotti, L.; Maier, J.A. Going to the roots of reduced magnesium dietary intake: A tradeoff between climate changes and sources. Helyion 2020, 6, e05390. [CrossRef]

71. Oh, H.E.; Deeth, H.C. Magnesium in milk. Int. Dairy J. 2017, 71, 89-97. [CrossRef]

72. Claeys, W.L.; Cardoen, S.; Daube, G.; De Block, J.; Dewettinck, K.; Dierick, K.; De Zutter, L.; Huyghebaert, A.; Imberechts, H.; Thiange, P.; et al. Raw or heated cow milk consumption: Review of risks and benefits. Food Control. 2013, 31, 251-262. [CrossRef]

73. Assefa, B. The Effect of Different Heat Treatment on the Nutritional Value of Milk and Milk Products and Shelf-Life of Milk Products. A Review. Dairy Vet. Sci. J. 2019, 11, 555822.

74. Corredig, M. Properties of the Milk Fat Globule Membrane Derived from Buttermilks from Different Sources. Ph.D. Thesis, University of Guelph, Guelph, ON, Canada, January 1998.

75. Öste, R.; Jägerstad, M.; Andersson, I. Vitamins in Milk and Milk Products. In Advanced Dairy Chemistry Volume 3; Fox, P.F., Ed.; Springer: Boston, MA, USA, 1997.

76. Park, Y.W. Impact of goat milk and milk products on human nutrition. Perspect. Agric. Vet. Sci. Nutr. Nat. Resour. 2007, 2, 1-19. [CrossRef]

77. Fantuz, F.; Salimei, E.; Papademas, P. Macro- and micronutrients in non-cow milk and products and their impact on human health. In Non-Bovine Milk and Milk Products, 1st ed.; Tsakalidou, E., Papadimitriou, K., Eds.; Elsevier Academic Press: London, UK, 2016; pp. 209-261.

78. Biadala, A.; Konieczny, P. Goat's milk derived bioactive components-A review. Mljekarstvo 2018, 68, 239-251. [CrossRef]

79. Jensen, S.K.; Nielsen, K.N. Tocopherols, retinol, b-carotene and fatty acids in fat globule membrane and fat globule core in cows' milk. J. Dairy Res. 1996, 63, 565-574. [CrossRef]

80. Zahar, M.; Smith, D.E. Vitamin A distribution among fat globule core, fat globule membrane, and serum fraction in milk. J. Dairy Sci. 1995, 78, 498-505. [CrossRef]

81. Conway, V.; Gauthier, S.; Pouilot, Y. Buttermilk: Much more than a source of milk phospholipids. Anim. Front. 2014, 4, 44-51. [CrossRef]

82. Fuller, K.L.; Kuhlenschmidt, T.B.; Kuhlenschmidt, M.S.; Jiménez-Flores, R.; Donovan, S.M. Milk fat globule membrane isolated from buttermilk or whey cream and their lipid components inhibit infectivity of rotavirus in vitro. J. Dairy Sci. 2013, 96, 3488-3497. [CrossRef]

83. Grune, T.; Lietz, G.; Palou, A.; Ross, A.C.; Stahl, W.; Tang, G.; Thurnham, D.; Yin, S.A.; Biesalski, H.K. Beta-carotene is an important vitamin A source for humans. J. Nutr. 2010, 140, 2268S-2285S.

84. Gallier, S.; Gordon, K.C.; Jiménez-Flores, R.; Everett, D.W. Composition of bovine milk fat globules by confocal Raman microscopy. Int. Dairy J. 2011, 21, 402-412. [CrossRef]

85. Patton, S.; Kelly, J.J.; Keenan, T.W. Carotene in bovine milk fat globules: Observations on origin and high content in tissue mitochondria. Lipids 1980, 15, 33-38. [CrossRef]

86. Wang, X.; Quinn, P.J. Vitamin E and its function in membranes. Prog. Lipid Res. 1999, 38, 309-336. [CrossRef]

87. Lindmark-Månsson, H.; Akesson, B. Antioxidative factors in milk. Br. J. Nutr. 2000, 84, S103-S110. [CrossRef] [PubMed]

88. Aiqian, Y.; Singh, H.; Taylor, M.; Anema, S. Interactions of whey proteins with milk fat globule membrane proteins during heat treatment of whole milk. Le Lait 2004, 84, 269-283.

89. Bulgari, O.; Caroli, A.M.; Chessa, S.; Rizzi, R.; Gigliotti, C. Variation of Vitamin D in Cow's Milk and Interaction with $\beta$ Lactoglobulin. Molecules 2013, 18, 10122-10131. [CrossRef]

90. Kanno, C.; Kanehara, N.; Shirafuji, K.; Tanji, R.; Imai, T. Binding form of vitamin B2 in bovine milk: Its concentration, distribution and binding linkage. J. Nutr. Sci. Vitam. 1991, 37, 15-27. [CrossRef] [PubMed] 
91. Sieber, R.; Eberhard, P.; Fuchs, D.; Gallmann, P.U.; Strahm, W. Effect of microwave heating on vitamins A, E, B1, B2 and B6 in milk. J. Dairy Res. 1996, 63, 169-172. [CrossRef]

92. Peterson, J.A.; Patton, S.; Hamosh, M. Glycoproteins of the human milk fat globule in the protection of the breast-fed infant against infections. Biol. Neonate 1998, 74, 143-162. [CrossRef] [PubMed]

93. Li, T.; Gao, J.; Du, M.; Mao, X. Milk fat globule membrane supplementation modulates the gut microbiota and attenuates metabolic endotoxemia in high-fat diet-fed mice. J. Funct. Foods 2018, 47, 56-65. [CrossRef]

94. EFSA NDA Panel (EFSA Panel on Dietetic Products, Nutrition and Allergies). Scientific Opinion on the essential composition of infant and follow-on formulae. EFSA J. 2014, 12, 3760. [CrossRef]

95. Corkins, K.G.; Shurley, T. What's in the Bottle? A Review of Infant Formulas. Nutr. Clin. Pr. 2016, 31, 723-729. [CrossRef]

96. Zavaleta, N.; Kvistgaard, A.S.; Graverholt, G.; Respicio, G.; Guija, H.; Valencia, N.; Lönnerdal, B. Efficacy of an MFGM-enriched complementary food in diarrhea, anemia, and micronutrient status in infants. J. Pediatr. Gastroenterol. Nutr. 2011, 53, 561-568. [CrossRef]

97. Billeaud, C.; Puccio, G.; Saliba, E.; Guillois, B.; Vaysse, C.; Pecquet, S.; Steenhout, P. Safety and tolerance evaluation of milk fat globule membrane-enriched infant formulas: A randomized controlled multicenter non-inferiority trial in healthy term infants. Clin. Med. Insights Pediatr. 2014, 8, 51-60. [CrossRef]

98. Holzmueller, W.; Kulozik, U. Isolation of milk fat globule membrane (MFGM) material by coagulation and diafiltration of buttermilk. Int. Dairy J. 2016, 63, 88-91. [CrossRef]

99. Spitsberg, V.L.; Ivanov, L.; Shritz, V. Recovery of milk fat globule membrane (MFGM) from buttermilk: Effect of Ca-binding salts. J. Dairy Res. 2019, 86, 374-376. [CrossRef] [PubMed]

100. Jash, A.; Ubeyitogullari, A.; Rizvi, S. Synthesis of multivitamin-loaded heat stable liposomes from milk fat globule membrane phospholipids by using a supercritical- $\mathrm{CO}_{2}$ based system. Green Chem. 2020, 22, 5345-5356. [CrossRef] 